\title{
Research on the Intelligent Traffic Information System Based on the Internet of Things -- Solving Parking Problems in Big Cities
}

\author{
Huijie Yang ${ }^{1, a,{ }^{*}}$ \\ ${ }^{1}$ School of Xi 'an peihua University, Xi 'an 710125, China \\ a 395436613@qq.com \\ *corresponding author
}

Keywords: The Internet of things; Parking status; The solution.

\begin{abstract}
At present, with the development of economy, people's standard of living is becoming more and more high, every family on the number of vehicles is also becoming more and more, it has created the problem of parking space nervous, and parking difficult to have such a situation in our country, not just in other countries, especially those in developed countries is quite serious; Many scholars are studying the problem of parking problems in big cities. By introducing the concept of Internet of things and related technologies, this paper constructs the structure of the parking information system of three major cities based on the Internet of things. This architecture includes homework layer, perception layer, network layer, application layer and user layer, a main body is a big city parking database is the core of the information transmission, three departments include traffic police supervision department, city management and cost management departments. Through this framework, the real-time control of the whole process information can be realized in the parking space, so as to guarantee the demand of urban consumers and promote the development of the stable and healthy urban transportation. The conclusion is to use the Internet of things and knowledge of intelligent transportation to build a system for solving the problem of parking problems in big cities so as to provide local governments with reference for solving urban parking problems.
\end{abstract}

\section{Introduction}

The parking of vehicles in big cities is crucial, both abroad and at home, and the problem of parking difficulties is quite serious. First of all, in the current situation of our country, with the rapid development of economy, the number of cars in our country has increased rapidly, especially the number of private cars has increased rapidly, occupying more than half of it. This leads to the shortage of cars and parking Spaces, which greatly affect the traffic condition of the city.At present, with the development of the technology revolution, such as the Internet and Internet of things, Profound influence on the transportation industry of big cities; In the social development, it is inevitable that the informationization process that fully combines the transportation industry and the Internet in big cities to promote the intelligent traffic is the place of the trend. The smart transportation has just started, and has opened up a new direction for the transformation and upgrading of transportation. Strengthen traffic information system design and implementation, can effectively improve the quality of the traffic management, solve the problem of city parking, safeguard the people's living standards, is of great significance to the reform of traffic supply side.

\section{Concept and Key Technologies of The Internet of Things}

The Internet of things (IOT) is based on the modern Internet (Internet) and mobile communication network information such as the media, will be independent of each other common object in the physical world to connect with each other and to implement the data exchange of information and network [2]. The important way to realize the "information" society is the Internet of things. Physical objects in the real world form an interactive network through the Internet of 
things. The Internet of things includes two meanings, one is that it is essentially no longer a pure Internet, but essentially an extension and extension of the Internet. The second is the terminal of the Internet of things.Is no longer running a desktop computer or electronic terminal equipment, but any object in real life, between them through the Internet to achieve the same or the exchange of information between different objects and contact. The concept of Internet of things can also be explained from the technical and practical aspects. From technical explanation, Internet of things is by means of the smart sensors installed in the object recognition various numerical characteristics of perceived object, and then through the Internet, to transmit the sensed data to the information processing center, so that between different objects can through information processing center, implementation of the automatic processing of data and information exchange; From practical level explanations, iot connects various objects in the world, and then through the existing Internet together, realizes the human society are connected with nature, which makes humans can more accurately perception and everything in the world, so as to improve the quality of our life. The key technology of Internet of things mainly include perception technology, network communication technology, data fusion and intelligent technology, nanotechnology, including perception technology is the base of iot technology, through a variety of types of sensors, acquisition perceived objects of all kinds of information, to realize the collection of information; Through the network communication technology to provide the information transmission channel between the various sensing objects; Data fusion and intelligent technology can process data collected to meet the needs of different users. Improving the use value of data; Nanometer technology is mainly to study the application of nanotechnology to the design of sensors to meet the needs of micro objects for sensors [3]. The Internet of things technology can be divided into the perceptual layer, the network layer and the application layer, and the perceptual layer is used for the collection of information. Network layer for information transmission; The application layer realizes intelligent control and the structure of the Internet of things through communication with customers (Table 1).

Table 1 Implementation of intelligent control, the structure of the Internet of things

\begin{tabular}{|c|c|c|c|c|}
\hline level & \multicolumn{4}{|c|}{ Content at all levels } \\
\hline \multirow{2}{*}{$\begin{array}{c}\text { The application } \\
\text { layer }\end{array}$} & $\begin{array}{c}\text { The environmental } \\
\text { monitoring }\end{array}$ & $\begin{array}{c}\text { Intelligent } \\
\text { transportation }\end{array}$ & $\begin{array}{c}\text { Intelligent } \\
\text { agriculture }\end{array}$ & Intelligent logistics \\
\hline & $\begin{array}{c}\text { Common } \\
\text { middleware }\end{array}$ & $\begin{array}{c}\text { Information open } \\
\text { platform }\end{array}$ & Cloud computing & $\begin{array}{l}\text { Service support } \\
\text { platform }\end{array}$ \\
\hline \multirow{2}{*}{$\begin{array}{c}\text { The network } \\
\text { layer }\end{array}$} & Internet & $\begin{array}{c}\text { Mobile } \\
\text { communication } \\
\text { network }\end{array}$ & $\begin{array}{l}\text { Private networks } \\
\text { (VPNS) }\end{array}$ & Remote control \\
\hline & $\begin{array}{l}\text { Next-generation } \\
\text { carrier network }\end{array}$ & $\begin{array}{c}\text { The wireless } \\
\text { network }\end{array}$ & $\begin{array}{l}\text { Heterogeneous } \\
\text { mesh fusion }\end{array}$ & $\begin{array}{l}\text { Resource and } \\
\text { storage } \\
\text { management }\end{array}$ \\
\hline \multirow[t]{2}{*}{ Perception layer } & $\begin{array}{l}\text { Sensor middleware } \\
\text { technology }\end{array}$ & $\begin{array}{l}\text { Self-organizing } \\
\text { networking } \\
\text { technology }\end{array}$ & $\begin{array}{l}\text { Collaborative } \\
\text { information } \\
\text { processing } \\
\text { technology }\end{array}$ & $\begin{array}{l}\text { Low speed and } \\
\text { medium high speed } \\
\text { short distance }\end{array}$ \\
\hline & The sensor & $\begin{array}{l}\text { Two dimensional } \\
\text { barcode }\end{array}$ & RFID & $\begin{array}{l}\text { Multimedia } \\
\text { information }\end{array}$ \\
\hline
\end{tabular}

\section{The Concept of Intelligent Transportation}

Intelligent transportation is based on information technology such as modern communication technology and network technology as the foundation, adopt various intellisense equipment such as RFID, operation in various vehicles and traffic facilities for real-time viewing and control, so as to realize automatic operation of the visualization of traffic management, traffic facilities management and intelligent signal management, improve the traffic efficiency. The premise of intelligent transportation is connectivity, foundation is data, core is integration, target is intelligence. The development stage of intelligent transportation can be divided into four stages: basic period, 
introduction stage, growth and maturity stage. The basic period mainly includes the construction of intelligent terminal and other perceptive equipment. Infrastructure construction of information infrastructure such as Internet and Internet of things, standards for communication between various devices and the construction of terminal agreements and other basic conditions; The introduction period mainly focuses on connectivity and realizes the real-time management of traffic operation; Through the deep integration of the Internet and the traditional transportation industry, a new value is created for the whole supply chain. The mature stage will realize the intelligent configuration of traffic resources through artificial intelligence, and create a smart transportation ecosystem. At present, China is in the transition from the basic stage to the transition of the intelligent traffic development stage.

\section{The Main Problem of Current Traffic Parking}

\subsection{Parking Fee Standard Is Low}

The first is the discussion of parking fee. Although there is a parking fee in the big city, it does not control the parking problem. The parking fee in the city is too chaotic and generally charged too low, and the city parking fee is mainly a means to control the parking time to regulate the supply and demand of the berth. But judging from the current parking problems in the city, the problem of charging for parking is not realized. Moreover, the parking fee structure is not very reasonable. The current situation is that the overall charging price is low, which does not serve the purpose of parking fee.

\subsection{Weak Parking Management}

In for parking management present a variety of patterns, disordered management and urban parking management mode in our country at present is not unified, there are many disadvantages in management in the bull management, management and the various departments. And at present, China's cities are basically the mode of artificial management, the sign and the line are not fully equipped.

\subsection{The Parking Equipment Cannot Meet The Parking Demand}

At present our country city needed for the construction of the parking lot with parking garages, so there is a case of road parking, parking and accessories standard is too low, many standards are not able to fully implement, causing traffic conflicts. At present, the urban parking lots of fundamental cannot solve the parking problem, according to the foreign empirical data show that when the total number of parking parking in the parking lot in the city can reach $20 \%$ of the motor vehicle can relieve urban parking problems.

\section{Construct the Framework of Intelligent Traffic Information System of Large Cities Based on the Internet of Things}

According to the current problems existing in the urban traffic information system, combined the technology of Internet of things, intelligence traffic building big city traffic integration of integrated information service platform, based on the Internet of the five layers of a main body three departments city intelligent traffic information system will be divided into five levels, a main body and three departments, five homework layer, perception layer, network layer, application layer and user layer. The main body is the parking database of big cities is the core of information transmission, and the three departments include traffic police supervision department, urban management department and cost management department. Through GPS and GIS system, it is possible to find parking Spaces in time to improve parking difficulties in big cities. Improve the efficiency of consumer travel; The analysis provided by the cost management system can reflect the cost and the formation of parking Spaces in big cities (Table 2). 
Table 2 The cost and the formation of parking Spaces in big cities

\begin{tabular}{|c|c|c|c|c|c|}
\hline level & \multicolumn{5}{|c|}{ Content at all levels } \\
\hline $\begin{array}{l}\text { The user } \\
\text { layer }\end{array}$ & $\begin{array}{l}\text { Government } \\
\text { regulators }\end{array}$ & $\begin{array}{l}\text { Scientific } \\
\text { research } \\
\text { institutions }\end{array}$ & $\begin{array}{c}\text { Research and } \\
\text { advisory } \\
\text { bodies }\end{array}$ & consumer & $\begin{array}{l}\text { Supply chain } \\
\text { middle and } \\
\text { downstream } \\
\text { transportation } \\
\text { enterprises }\end{array}$ \\
\hline $\begin{array}{c}\text { The } \\
\text { application } \\
\text { layer }\end{array}$ & $\begin{array}{c}\text { Original } \\
\text { traffic } \\
\text { information } \\
\text { collection }\end{array}$ & $\begin{array}{l}\text { Information } \\
\text { collection of } \\
\text { traffic } \\
\text { operation } \\
\text { process }\end{array}$ & $\begin{array}{l}\text { The } \\
\text { information } \\
\text { collection of } \\
\text { parking infor- } \\
\text { mation in the } \\
\text { city of xi 'an }\end{array}$ & $\begin{array}{l}\mathrm{Xi} \text { 'an high } \\
\text { and new, } \\
\text { qujiang } \\
\text { parking } \\
\text { information } \\
\text { collection }\end{array}$ & $\begin{array}{l}\mathrm{Xi} \text { 'an baqiao, } \\
\text { chang 'an } \\
\text { district, lintong } \\
\text { district parking } \\
\text { information } \\
\text { collection }\end{array}$ \\
\hline $\begin{array}{c}\text { The } \\
\text { network } \\
\text { layer }\end{array}$ & $\begin{array}{l}\text { Traffic hall } \\
\text { Internet of } \\
\text { things } \\
\text { management } \\
\text { system }\end{array}$ & $\begin{array}{l}\text { Traffic bureau } \\
\text { Internet of } \\
\text { things } \\
\text { management } \\
\text { system }\end{array}$ & $\begin{array}{l}\text { The Internet of } \\
\text { things } \\
\text { management } \\
\text { system in xi 'an } \\
\text { city }\end{array}$ & $\begin{array}{l}\mathrm{Xi} \text { 'an high - } \\
\text { tech, qujiang } \\
\text { iot } \\
\text { management } \\
\text { system }\end{array}$ & $\begin{array}{l}\mathrm{Xi} \text { 'an baqiao, } \\
\text { chang 'an } \\
\text { district, lintong } \\
\text { district iot } \\
\text { management } \\
\text { system }\end{array}$ \\
\hline $\begin{array}{l}\text { Perception } \\
\text { layer }\end{array}$ & RFID video & sensor & $\begin{array}{c}\text { Video } \\
\text { acquisition } \\
\text { device }\end{array}$ & $\begin{array}{c}\text { GPS } \\
\text { positioning } \\
\text { device }\end{array}$ & $\begin{array}{l}\text { GIS geographic } \\
\text { information } \\
\text { system }\end{array}$ \\
\hline $\begin{array}{l}\text { Homework } \\
\text { layer }\end{array}$ & $\begin{array}{l}\text { Acquisition } \\
\text { phase }\end{array}$ & $\begin{array}{l}\text { Analytical } \\
\text { data phase }\end{array}$ & $\begin{array}{l}\text { The parking } \\
\text { phenomenon is } \\
\text { announced }\end{array}$ & $\begin{array}{c}\text { Stop the } \\
\text { parking } \\
\text { phenomenon }\end{array}$ & $\begin{array}{c}\text { The result of the } \\
\text { parking } \\
\text { phenomenon }\end{array}$ \\
\hline
\end{tabular}

\section{A Solution to The Problem of Parking Problems Abroad}

Moscow's enclosure, for example; Parisians stop in their buildings; London is a time delay; Sydney creates conditions for parking; It's worth learning.

\section{Analyze the Parking Difficulty Strategy}

\subsection{Laws and Regulations}

First of all, Japan promulgated the parking lot law in 1957 and promulgated the parking lot law enforcement order. China's Taiwan province in 1991, implemented the act of parking lot, also in adjusted by the rule of law to the parking problem, say so on the basis of the rule of law for parking penalties also greatly strengthened and implemented, so as to make the parking reduced to the minimum degree.

\subsection{Management}

First, parking fee management; Secondly, parking management is a matter of people's livelihood. Thirdly, it is suggested to consider the relationship between static traffic and dynamic traffic, and make a long-term plan for the proportion of parking facilities, especially the proportion of parking Spaces.

\section{References}

[1] hangdong. How to solve parking problems in big cities abroad [J]. Transportation and transportation, 2011,06.

[2] dong suhua. Research on urban parking problems [J]. Urban vehicle, 2011,04.

[3] wu hongli, yi fei. Urban parking problems and countermeasures [J]. Shanxi architecture, 2010.2 